\title{
ASIAN Foreign DiReCt InVESTMENTS IN THE VisegRAd COUNTRIES: What ARE Their Motivations FOR COMING INDIRECTLY?
}

\author{
Andrea S. Gubik ${ }^{1}$, Magdolna Sass ${ }^{2}$, Ágnes Szunomár ${ }^{3}$
}

\begin{abstract}
Asian foreign direct investments are significant in the Visegrad countries (Czech Republic, Hungary, Poland and Slovakia). Statistics compiled by the OECD's new balance of payments manual (BPM6) show that the FDI stock of Asian investors is significantly higher than the data on direct investors suggest, meaning that companies go through intermediary countries before the investment reaches its final destination. The purpose of the article is to analyse why Asian FDI invest through intermediaries rather than directly. The paper analyses the main reasons for this "indirectedness" based on statistical data, other sources and semi-structured interviews with automotive and electronics companies. Our results show that the motivations for using an intermediary country can be manifold. Tax optimisation is often the reason why a company goes through a country with a more favourable regulatory environment. In addition, the geographical distance and global production chain considerations can be important, as well as the aim of companies from emerging countries to conceal the investor's real origin. The increasing number of acquisitions further enhances the share of indirect investments, as with the acquisition of a foreign parent company the new owner also inherits its subsidiaries.
\end{abstract}

\section{Keywords}

Foreign Direct Investments, Asian Multinational Companies, Ultimate Investing Country, Visegrad Countries

\section{Introduction}

After the transition process from the planned to the market economies started, with different timing, all Visegrad countries opened up their economies to foreign direct investments, realised by foreign multinational companies. While in the nineties there was a clear dominance of multinationals from Western European and other developed

\footnotetext{
${ }^{1}$ University of Miskolc, 3515-Miskolc-Egyetemváros, Hungary. E-mail: getgubik@uni-miskolc.hu.

${ }^{2}$ Centre for Economic and Regional Studies and Budapest Business School, 1097 Budapest, Tóth Kálmán utca 4, Hungary. E-mail: sass.magdolna@krtk.mta.hu.

${ }^{3}$ Corvinus University of Budapest and Centre for Economic and Regional Studies, 1097 Budapest, Tóth Kálmán utca 4, Hungary. E-mail: szunomar.agnes@krtk.mta.hu.
} 
countries (mainly the United States and Japan), later on multinationals from other nondeveloped countries, among them Asian companies, started to discover this destination for their foreign direct investments. (Kaliszuk, 2016), for example, shows the different timing and paths of South Korean and Chinese FDI in Poland.) Important projects realised in the Visegrad countries by Asian investors include those by companies from Japan (Matsushita, Suzuki, Mitsubishi, Toyota, Sanoh, Alpine, Sumitomo, Panasonic and Asahi Glass), Korea (Samsung, Hankook and Hyundai), China (Huawei, ZTE, Lenovo, Wanhua), India (SMR, Apollo Tyres and Tata), Singapore (Patec) and Taiwan (Foxconn (Hon Hai)), just to name a few. At present, Asian foreign direct investments are much more substantial in these countries than we previously thought, which will be the first topic we deal with in this article. These investors usually come through intermediary countries to the Visegrad countries, which means that before reaching the final Visegrad destination, their investments usually flow through another country or countries. Besides the geographic distance, there can be other motivations for such an approach - this is the second topic we deal with in this article. Based on company interviews conducted in Hungary and other data collected from newspaper articles and specialised economic daily articles, we draw up a list of the various motivations behind this intermediary nature of Asian foreign direct investment in the Visegrad countries.

As the necessary statistics were not available and multinational companies used a range of intermediary countries for FDI, the importance of Asian FDI in the region has remained hidden to society and, in part, to the professional community. Our work aims to help both decision-makers and researchers in exploring the extent of FDI from Asia and in understanding their motivations for an indirect appearance in other nations.

As Hungary is representative of the Visegrad countries in terms of geographic position, FDI attraction and level of development (GDP per capita), which are all important factors when it comes to explaining FDI attraction, the experiences in Hungary can be generalised to the Visegrad countries and to other countries in the region. After describing the role of Asian foreign direct investments (FDI) in the Visegrad countries, the purpose of the article is to analyse why Asian FDI comes through intermediaries rather than directly. Our article is organised as follows. After the brief introduction, we present the data about Asian FDI in the Visegrad countries. Next, we describe briefly our methodology and then present the results of our research. In the last section we present our conclusions.

\section{Asian FDI in the Visegrad countries}

FDI data are now available according to the Ultimate Investing Country (UIC) principle, where FDI is assigned to the country of the foreign investor that ultimately controls the investments in the host economy (OECD, 2015). Thus, we have a clearer picture about how much FDI from Asia is invested in the four Visegrad countries: the Czech Republic, Hungary, Poland and Slovakia. Previously, FDI data were broken down according to the nationality of the immediate investor, and as Asian multinationals quite often go through other countries before the investment reaches its final destination, this resulted in a low value and share in total for Asian FDI in the Visegrad group. The latest BPM6 FDI data are available for the analysed countries for 2017, and they are broken down according to 
ultimate investors and according to direct investors (Table 1). This enables us first to gain a more accurate picture of the real extent of Asian FDI in the four analysed countries, and what the main source countries are in that respect. Furthermore, we are able to show the difference between FDI coming directly from Asia and the overall stock of FDI of Asian origin in the Visegrad region, and thus the level of inclination of Asian investors to go through intermediary countries. Additionally, we can go down to the country level to show differences between the two values as well as between the investor countries. Unfortunately, Slovakia presents data according only to the direct investors' country breakdown, thus it is left out of certain analyses. However, according to Grešš (2019), China, Taiwan, South Korea and Japan are important Asian investors in Slovakia. On the other hand, according to FATS data of the Eurostat, the number of Asian-owned companies in Slovakia is very small compared to the other three Visegrad countries (for Chinese and Hong Kong-owned companies see Sass (2019), for their negligible share in total FDI see Pleschová (2017)).

Table 1: FDI stock by leading Asian investor countries in the Visegrad countries, 2017 (million USD)

\begin{tabular}{|l|r|r|r|r|r|r|r|r|}
\hline & \multicolumn{2}{|c|}{ Czech Republic } & \multicolumn{2}{c|}{ Hungary } & \multicolumn{2}{c|}{ Poland } & \multicolumn{2}{c|}{ Slovakia } \\
\hline & \multicolumn{1}{|c|}{ direct } & ultimate & \multicolumn{1}{c|}{ direct } & ultimate & direct & ultimate & direct & ultimate \\
\hline Japan & 1907.66 & 3314.14 & 1152.56 & 3185.93 & 887.43 & 4996.26 & 125.16 & n.d. \\
\hline Korea & 3254.71 & 3046.01 & 1979.25 & 1986.48 & 1134.81 & 1783.54 & 3535.08 & n.d. \\
\hline China & 707.27 & 1096.04 & 210.96 & 1973.42 & 223.11 & 826.51 & 55.12 & n.d. \\
\hline Hong Kong, China & 115.69 & 204.41 & 319.81 & 207.51 & 347.08 & 465.06 & 25.03 & n.d. \\
\hline India & -1.12 & 99.51 & -16.04 & 2657.56 & 103.38 & 299.41 & -2.72 & n.d. \\
\hline Singapore & 344.64 & 699.07 & 532.29 & -55.72 & 84.74 & 109.56 & 118.49 & n.d. \\
\hline Chinese Taipei & 283.53 & 1007.46 & 47.28 & 971.91 & 30.76 & 254.14 & 18.27 & n.d. \\
\hline \hline Sum of 7 countries & 6612.36 & 9466.65 & 4226.11 & 10927.09 & 2811.31 & 8734.48 & 3874.42 & n.d. \\
\hline $\begin{array}{l}\text { Sum of 7 countries } \\
\text { in \% of total FDI } \\
\text { stock }\end{array}$ & 4.42 & 6.33 & 4.64 & 12.01 & 1.18 & 3.66 & 6.94 & n.d. \\
\hline
\end{tabular}

Source: OECD FDI positions by partner country BMD4: Inward FDI by immediate and by ultimate investing country and Hungary: Hungarian National Bank

Asian FDI is considerably greater according to the data on the ultimate owners' country compared to the direct owners data in all three Visegrad countries for which data are available - based on that, we can assume that the case is so in Slovakia as well. Differences between the direct and ultimate data are large, especially in Hungary and Poland.

According to the data, the leading Asian investors differ in the three countries: while Japan is the top investor in all three countries, Korea is second in the Czech Republic and Poland, but only third in Hungary, while this country may be the leading investor in Slovakia. Hungary has very substantial FDI stock originating from India, which is its 
second largest investor country. China ranks third (in the Czech Republic and in Poland) or fourth (in Hungary). Chinese Taipei ranks fourth in the Czech Republic and fifth in Hungary.

In terms of their share in total, the seven leading Asian investor countries represent more than $12 \%$ of all FDI in Hungary, more than $6 \%$ in the Czech Republic (and most probably in Slovakia) and more than 3\% in Poland. In all cases their share is considerably larger according to the ultimate owners' country than according to the direct owners' country. The difference is the largest in the case of Hungary; where Asian investors appear to be the most inclined to go through intermediary countries.

Figure 1: FDI stock of the leading Asian investors in Visegrad 3 (Czech Republic, Hungary, Poland), 2017 (million USD)

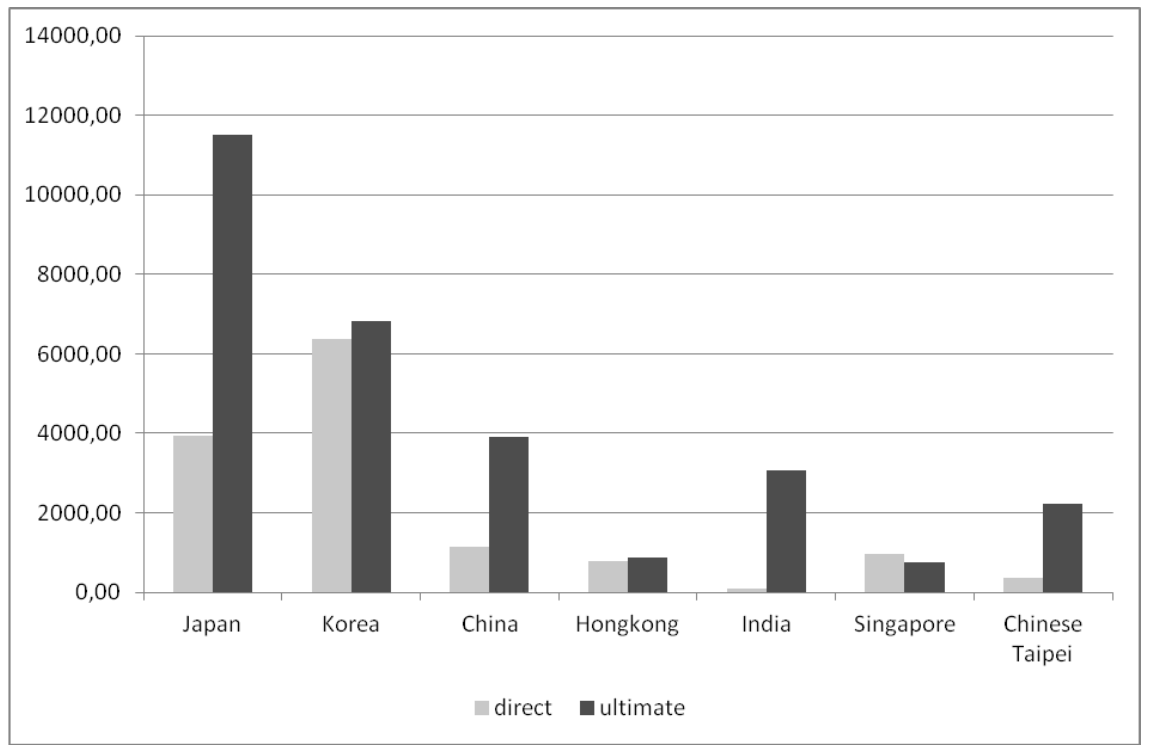

Source: own calculations based on OECD FDI positions by partner country BMD4: Inward FDI by immediate and by ultimate investing country and Hungary: Hungarian National Bank

Based on the summarised Asian country level data (Figure 1), Korean, Hong Kong and Singapore multinationals usually invest directly from their home countries, as in their case the difference between the data according to the ultimate and direct investor countries is the smallest. On the other hand, the FDI of Japanese, Chinese and especially Indian and Chinese Taipei multinational firms usually passes through another country (or countries) before reaching its final destination in a Visegrad country. In the literature there are some hints at this "indirectedness" of Asian FDI in the Visegrad countries. Szabo (2019) noted that many outside-European investors come through a European country (usually the Netherlands or Luxembourg) to the Visegrad countries. The same is shown by Varga (2018). EIAS (2014) showed that Taiwanese (Chinese Taipei) FDI to Europe, and to its main Central and Eastern European (CEE) destinations of Czech Republic, Hungary and 
Poland, may flow through the Netherlands. Sass (2019) showed that Chinese investments usually go through an intermediary country before they arrive in a Visegrad country. Going down to the company level, we found interesting cases where the Asian investor went through an intermediary country before reaching its final Visegrad destination. For example, the Hungarian Samsung subsidiary is the parent of subsidiaries in the Czech Republic and Slovakia (and Romania) of the Korean firm, thus there the Korean company is present indirectly, through Hungary. On the other hand, Samsung invested directly in Hungary, i.e. its FDI originates directly from Korea (Sass, 2016).

Two Indian companies, Apollo Tyres and Sona, invested in Hungary indirectly, through the Netherlands, while Tata is a direct investor, thus its FDI comes directly from India into the Visegrad countries. The Chinese Huawei realises its investments in the Visegrad countries mainly through its Dutch subsidiary (Sass et al., 2019). McCaleb (2018) describes the route of Chinese FDI to Poland, going usually through Hong Kong, the Netherlands, Luxembourg, Switzerland, etc.

It is obvious that for certain multinationals, it is important to sandwich an intermediary country between the original and final destination of its investments. Our main area of investigation is why is this so? What can be the main motivation of going through an intermediary country when establishing a foreign subsidiary?

\section{Methodology}

In order to find out what the main motivations can be for using intermediary countries in Asian direct investments realised in the Visegrad countries, we conducted interviews with managers of ten Chinese, Indian, Japanese, and Korean-owned subsidiaries in Hungary. The choice of Hungary is supported by the fact that it is a relatively important host to Asian investments in the Visegrad group and it has the largest difference between FDI coming directly and ultimately from Asia. There are four Japanese, three Chinese, two Indian companies and one Korean firm in our sample. The semi-structured interviews were conducted by the authors between December 2016 and December 2019 (Table 2). All interviewees were guaranteed confidentiality. The answers were noted down by the authors in detail and were then analysed. The number and length of interviews did not justify the use of qualitative data analysis software or applying any coding techniques.

We asked the following questions during our semi-structured company interviews:

1. What are the main characteristics of the company (year of establishment, year of establishment in Hungary, ownership structure, changes in ownership structure, entry mode)?

2. What is the country of the ultimate owner of the investment and of the direct owner of the investment? If these two differ - what is the reason for that?

3. What were the main reasons for selecting Hungary for the location of the investment?

4. How independent is the subsidiary in terms of making decisions? 
We have to note that our access to the subsidiaries in question was not without problems. In certain cases, it took a long period of time and negotiations to get in touch with the management of the companies in question (usually with the help of an intermediator, for example a representative of an industry association, of a ministry etc.). This limited access explains the low number of companies in our sample and the fact that our sample is not representative. However, we were able to access some "flagship" Asian-owned subsidiaries in Hungary, some companies that are present in another Visegrad country as well, and some of minor importance; that is why we believe our results based on the "mix" of companies in our sample are generalisable. Information from the company interviews was supplemented by data from the balance sheets and webpages of the subsidiaries.

Table 2: Details of the interviews conducted in the framework of the research

\begin{tabular}{|c|c|c|c|c|}
\hline $\begin{array}{l}\text { Company } \\
\text { No. }\end{array}$ & $\begin{array}{l}\text { Year of establish- } \\
\text { ment/acquisition }\end{array}$ & Entry mode & $\begin{array}{c}\text { Number of } \\
\text { employees at present }\end{array}$ & Date of interviews \\
\hline 1 & 1989 & greenfield & $\begin{array}{l}2500 \text { permanent }+ \\
500 \text { seasonal }\end{array}$ & 12 April 2017 \\
\hline 2 & 2005 & greenfield & $\begin{array}{l}330 \text { (white-collar, } \\
\text { directly) }+2500 \\
\text { (blue-collar, } \\
\text { indirectly) }\end{array}$ & $\begin{array}{l}4 \text { times between } \\
\text { the winter of } 2016 \\
\text { and April } 2017\end{array}$ \\
\hline 3 & 1991 & greenfield & $\begin{array}{c}3000 \text { permanent }+ \\
200 \text { seasonal }\end{array}$ & April 2017 \\
\hline 4 & $\begin{array}{l}\text { One in } 2009 ; \\
\text { Second in } 2011 ; \\
\text { Third in } 2016\end{array}$ & brownfield & 2400 altogether & January 2017 \\
\hline 5 & 2006 & brownfield & 850 altogether & December 2016 \\
\hline 6 & 2017 & $\begin{array}{l}\text { acquisition } \\
\text { (the acquired } \\
\text { plant was } \\
\text { established } \\
\text { through } \\
\text { a greenfield } \\
\text { investment) }\end{array}$ & 2000 & April-May, 2019 \\
\hline 7 & 1998 & greenfield & $650-700$ & May, 2019 \\
\hline 8 & 2017 & brownfield & 260 & May, 2019 \\
\hline 9 & 1997 & greenfield & 4000 & September, 2019 \\
\hline 10 & 2006 & greenfield & 180 & December, 2019 \\
\hline
\end{tabular}

Source: own compilation based on company interviews conducted in the framework of the research 
The subsidiaries we interviewed employ a total of about 19,500 people in Hungary. This accounts for 12.2 percent of all workers employed in the sector ${ }^{4}$, taking into account the employment statistics of categories Computer, electronics, optical product manufacturing (which is a common category according to the TEÁOR classification), and motor vehicle manufacturing activities. If the comparison is made with the employment statistics of foreign subsidiaries, the companies surveyed account for 15.1 percent of total sectoral employment. $^{5}$

Our qualitative research justifies why we rely on company interviews: in-depth information on the various motivations to invest indirectly could only be obtained through interviews. This type of methodology of relying on interview-based company case studies has both advantages and disadvantages. An advantage is that we have obtained detailed quantitative and qualitative data in the analysed areas and on their development over time. At the same time, a drawback of our methodology is that the low number of companies in the sample and their industries do not allow us to generalise our conclusions.

\section{Results of our research}

The "real" home country of the foreign investor and the direct investing country may differ from each other - and this seems to be increasingly true over time. Since the 1990s, there has been an increase in indirect FDI where the ultimate and direct source countries differ from each other (Antalóczy and Sass, 2015). According to estimations, indirect FDI can represent up to one third of the total FDI stock in the world economy (Damgaard and Elkjaer, 2017). This of course raises the question of the reliability of FDI statistics as well. In Europe, the offshore centres, which play the intermediary role between the ultimate home country and the host country of the investment and usually serve tax optimisation purposes, own $11 \%$ of foreign-owned EU companies (European Commission, 2019). Our region is also affected by this problem, as was shown by Altzinger and Bellak (1999). There are very few research studies, which examine the motivations of indirect FDI. According to Kalotay (2012), the reasons for using an intermediary country can be: tax optimisation, better knowledge of and/or geographic proximity to the final destination economy, concealing the real origin of the investment or nominating a regional headquarter, which then is the owner of all regional FDI. According to Andreff (2016), the use of intermediary countries is especially characteristic of emerging multinational firms. The stronger Asian presence than previously thought raises several questions. What can be the motivations of investors for using intermediary countries? Could there be another special reason, independent of the corporate strategy, for investing indirectly from the home country of the multinational company? In this article, we look for answers to these questions based on information from company interviews and other data sources.

The Hungarian subsidiaries of the Asian multinational companies in the sample are characterised by the following features in terms of our topic.

\footnotetext{
${ }^{4} \mathrm{KSH}(2018)$.

${ }^{5} \mathrm{KSH}(2017)$.
} 
Table 3: Characteristics of the companies in our sample by the use of an intermediary country and type of the entry mode

\begin{tabular}{|c|c|c|c|}
\hline Company & $\begin{array}{c}\text { Has it come directly or } \\
\text { through an intermediary } \\
\text { country? }\end{array}$ & $\begin{array}{c}\text { If it came through an } \\
\text { intermediary country, } \\
\text { which is that? }\end{array}$ & $\begin{array}{c}\text { Entry mode: } \\
\text { greenfield or } \\
\text { acquisition }\end{array}$ \\
\hline 1 & direct & Netherlands & greenfield \\
\hline 2 & through intermediary & direct & Cyprus \\
\hline 3 & through intermediary & Netherlands & acquisition \\
\hline 4 & through intermediary & Luxembourg & acquisition \\
\hline 5 & through intermediary & Hong Kong, China & greenfield \\
\hline 6 & through intermediary & Switzerland & acquisition \\
\hline 7 & through intermediary & Netherlands & greenfield \\
\hline 9 & through intermediary & & greenfield \\
\hline 10 & & direct & \\
\hline
\end{tabular}

Source: own compilation based on the company interviews

Based on our relatively small sample, we can confirm what is reflected at the macrolevel FDI data published by the Hungarian National Bank: Indian, Japanese and Chinese investors are more likely to invest in Hungary through an intermediary country, while Korean multinational companies almost always invest directly from their home country. (Actually, this is more or less true for the other two Visegrad countries, for which data are available in Table 1: for Korean investors, the difference between the direct and the ultimate data is minor in the three Visegrad countries, while for Indian, Japanese and Chinese investors the difference is substantial.) In our sample, investment in Hungary through intermediary countries is significant: eight out of ten companies chose this option ${ }^{6}$. Investors from less developed countries may also aim to conceal the true nationality of the investor (Kalotay, 2012); in addition to geographical distance, this may also contribute to the use of an intermediary country. Chinese and Indian investors also tend to flow through different tax havens or countries with favourable tax opportunities (this is shown for BRICS ${ }^{7}$ by Andreff (2016), for India by Pradhan (2017), for China by Seaman et al. (2017), Huang and Xia (2018) and the European Commission (2019), and here too the motivation to conceal the true nationality of the owner may arise (European Commission, 2019). In general, investment from Japan and South Korea is much less characterised by this aim of hiding the real origin of the investment (Table 4).

\footnotetext{
${ }^{6}$ The country of origin of the investors is not disclosed due to the anonymity promised to the interviewed companies.

${ }^{7}$ The BRICS abbreviation refers to the following countries: Brazil, Russia, India, China and South Africa.
} 
Table 4: Japanese and South Korean FDI in offshore centres in percentage of the total outward FDI, 2017

\begin{tabular}{|l|c|}
\hline & Share of offshore centres in total outward FDI stock \\
\hline South Korea & $6.4 \%$ \\
\hline Japan & $3.5 \%$ \\
\hline
\end{tabular}

Note: Favoured offshore centres according to IMF (2014): Japan - Cayman Islands, Malaysia; South Korea - Unpublished data for the British Virgin Islands, Cayman Islands, Cyprus, Guernsey, Jersey, Macao, Malaysia, Palau, Panama (no published data is available in the case of the Bahamas, Belize, Bermuda, Isle of Man, Seychelles and Samoa due to the low number of investor companies and hence their identifiability).

Source: OECD (https://stats.oecd.org/Index.aspx?QueryId=64220)

Related to the previous motivation and a much more important objective for investor companies is tax optimisation. The relevance of this is supported by the fact that in six cases in our sample, companies use European countries with favourable tax opportunities as intermediary countries (Andreff, 2016; Antalóczy and Sass, 2015). The importance of the Netherlands can be seen, where the so-called Dutch sandwich indicates that it is worthwhile to set up a favourably-regulated Dutch subsidiary between the investor's home country and the host country (Antalóczy and Sass, 2015). (In the case of Company 7 , Hong Kong is the intermediary country, which also is favourably taxed, but the company originally came to Hungary directly from the home country when it first appeared. We have to note that in this case, the ultimate owner's country is not China.) Varga (2018) also highlights the importance of the motivation of tax optimisation in case of capital investment in the Visegrad countries from outside Europe. He shows that the role of nonoffshore developing countries among the main non-European partners is greater in terms of the final origin of investments than in their direct origin.

In addition to tax optimisation, reducing other bureaucratic burdens in the home country could also be an objective. In our sample, we see an example for this in the case of Company 7, where the company headquarters were relocated from its home country to Hong Kong. The company had already set up a Hong Kong subsidiary in 1986 and has significant foreign capital investments, primarily in Asia. The headquarters were transferred to Hong Kong only in 2004, with the aim of reducing the bureaucratic burden for the international operations of the company.

In this context, due to the low number of cases, we can draw a tentative conclusion that acquisitions cause an appearance rather through an intermediary country, whereas for greenfield investments, investors come directly from the home country. Thus, the reason why a multinational company indirectly appeared in Hungary was the acquisition of another (non-Hungarian) multinational company that had subsidiaries in Hungary. Thus, the new owner inherited the Hungarian subsidiaries of the third country company by acquiring their direct parent company. In this case, the Asian investor also appears through an intermediary country in Hungary, but for the practical reasons mentioned above. In 
our sample, the foreign (German) parent company of Company 4 was acquired by an Indian multinational company, while Company 6 was also acquired by a Chinese company through several acquisitions, thus becoming the owner of the Hungarian subsidiary of an Asian company. Here it was not the parent company but the subsidiary itself that was acquired. Thus, the real motivation for foreign investment is not related to the direct entry or entry through an intermediary country (as in the case of tax optimisation), but, another reason can be, as in the case of Company 6 , that the acquisition of a competitor takes place. (Nevertheless, the final European headquarters of the companies will remain in a country with favourable taxes, such as Cyprus or Luxembourg.)

We find further examples of such "inherited" subsidiaries which, in practice, automatically own the Hungarian company through an intermediary country (often the home country of the previous owner of a multinational company). For example, China's Yanfeng, which was not among the companies interviewed, became a Hungarian investor through a merger with the American Johnson Controls, meaning that the Hungarian factory, which was owned by the US company, became 50 percent Chinese owned. ${ }^{8}$ Another interesting example involves three Visegrad countries - among other economies. The Chinese Wanhua Group acquired full control of the Hungarian BorsodChem chemical company in 2011 in a 1.2 billion euro deal. ${ }^{9}$ Thus, BorsodChem subsidiaries in other seven countries, including the Czech Republic and Poland, which were beforehand the subsidiaries of a Hungarian multinational firm, have become now indirectly owned subsidiaries of the Chinese multinational. ${ }^{10}$

There may also be a link between the management of the acquisition, the integration of the acquired company into a multinational corporate network and the existence of the intermediary country. It may be particularly important to appoint a regional centre if the value chains are predominantly organised on a regional basis under the leadership of the multinational firm. It is assumed that this is the case in Company 1, since the company came directly from the mother country; however, the Hungarian subsidiary is the parent company of several regional subsidiaries, so in these countries of the region it appears indirectly through the Hungarian subsidiary. In addition, the Western European production units were gradually relocated to Central and Eastern Europe (within that mainly Hungary and Poland), so relocation of the continental headquarters was also a reasonable option in the given situation. Another such example can be those of the Japanese multinationals: according to our interviews, while "smaller-sized" Japanese multinational firms (such as for example Suzuki) come directly from Japan to the host country, large Japanese multinational companies (such as for example Toyota) usually operate with continental or regional headquarters. This results in a mix of direct and indirect presence of Japanese multinationals, which is reinforced by our interviews. Furthermore, based on Table 1, we can state that the situation seems to be the same in the Czech Republic and Poland. The relevance of the continental organisation is also demonstrated by the fact that the information collected during the interviews confirms the results of the literature that the

\footnotetext{
${ }^{8}$ Content (2015).

${ }^{9}$ Bryant (2011).

${ }^{10}$ BorsodChem. Location/Contacts. Retrieved from http://www.borsodchem-group.com/Locations.aspx.
} 
main type of Asian FDI is market-seeking investment: by entering the Hungarian market, Asian companies not only gain access to the European Union (and domestic) markets but also to markets of Commonwealth of Independent States, Mediterranean countries and EFTA (European Free Trade Association). During the interviews, representatives of almost all the companies emphasised that their presence in Central and Eastern Europe was to join their existing business in Western Europe or to strengthen their European market position in the broader sense.

All in all, although the motivation for tax optimisation dominates, there are other reasons that may play a role in the use of the intermediary country, which we have found to be very common in the case of Asian investing countries, and especially in the case of the emerging countries.

The examples above illustrate the need to differentiate the cases not only according to the use or non-use of the intermediary country but also the motivations and so the actual execution of the transaction is important. The examples of Yanfeng and BorsodChem/Wanhua draw attention to the fact that indirect FDI is a result of acquisition. In the case of acquisitions, we also find differences depending on whether the parent company has been acquired itself or only one subsidiary has been bought. In the latter case, the new parent can invest directly or indirectly, while in the former case (acquisition of the parent) it is always indirect. As the number of mergers and acquisitions in the EU is increasing (European Commission, 2019), the role of such inherited subsidiaries can be expected to grow.

The time factor also seems to be important. Due to our small sample, we can only assume that companies investing directly in Hungary arrived in the country in the late 1990s and early 2000s (in the case of Company 7 the investment was inherently direct). Meanwhile, as a result of the knowledge and experience accumulated in the companies, and the companies' efforts to optimise the global production chains and so to reduce tax payments, their structure has become increasingly complex, with the location decisions about headquarters and production activities resulting in a multi-country structure.

Last but not least, the prominent role of offshore centres should be mentioned. These offer specific tax and regulatory advantages for the companies. (This may result in fiscal erosion not only in the home country, but in all affected economies, including the host and intermediary countries.) Cultural differences should be mentioned above all. While Japanese companies do not use tax havens for tax purposes and Korean companies typically do not, Chinese companies often do use tax havens. 


\section{Conclusion}

In the world economy, in Europe and in Hungary there has been an increase in Asian investments in the last decades. Their true extent can be specified based on the new FDI data published for the years after 2014, which present these data according to both the ultimate owner and the direct owner of the investment. Based on these new data we can state that first, the extent and share of Asian FDI in total is larger in the Visegrad countries than we had previously thought and second, that Asian investors, compared to their European counterparts, are more inclined to pass their investments through a third country, before it reaches its final location. Thus they come to the Visegrad countries mainly indirectly, via intermediary countries.

In our article, based on company interviews, we wanted to analyse what the reason can be for this "indirectedness". We conducted interviews with leading managers of ten subsidiaries of Asian multinationals in Hungary. We deem that the reasons for indirectedness can be similar in the other three Visegrad countries.

According to our results, the motivations for using an intermediary country can be manifold. Besides the geographic distance, especially emerging multinational companies may want to conceal their real origin by sandwiching in an intermediary country between the host and ultimate home country. Furthermore, production organisation reasons may also matter, especially in global value chain related activities. We found the tax optimisation reason quite widespread, sometimes going together with the motivation of decreasing bureaucratic burdens. In the case of the Visegrad countries, the role of inherited subsidiaries can also be important: when an Asian multinational firm acquires the parent firm, it inherits its subsidiaries in the Visegrad countries - and this practical reason results in the use of an intermediary country.

We conducted interviews with a total of ten Asian subsidiaries, in which we interviewed senior executives with relevant knowledge and employees working for the company for several years. However, there can be a selection bias concerning the firms, as there is a low number of firms in our sample and we interviewed companies operational in two industries: automotive and electronics only. That is why our results may not be generalisable. Another limitation of our work is that we only interviewed Hungarian subsidiaries, and we only met with the staff of the subsidiaries (both foreign and Hungarian employees were asked) and did not directly seek the opinion of the parent company's decision makers.

However, these also indicate avenues for further research. Besides these possible extensions of our research, we can also analyse whether there is a difference between the host country impact and the different characteristics of firms (way of operation, performance etc.) coming directly vis-à-vis those that invest indirectly. There can be differences according to the industries and activities as well, especially in services. The limitations and the new and relevant research questions indicate that our present work is only one of the first steps in exploring the motives and consequences of using an intermediary country during foreign direct investments. 


\section{Acknowledgement}

The authors are grateful for financial support provided by the PAIGEO Fund. Magdolna Sass's research was also supported by the Hungarian Research Fund NKFIH (no. 132442), while Ágnes Szunomar's research was supported by the Bolyai János Research Fellowship of the Hungarian Academy of Sciences and the New National Excellence Program (ÚNKP20-5-CORVINUS-29).

\section{References}

Altzinger, W., Bellak, C. (1999). Direct versus Indirect FDI: Impact on Domestic Exports and Employment. Working Paper Series: Growth and Employment in Europe: Sustainability and Competitiveness No. 9. Vienna University of Economics and Business Administration, Vienna, November.

Andreff W. (2016). Outward Foreign Direct Investment from BRIC countries: Comparing strategies of Brazilian, Russian, Indian and Chinese multinational companies. The European Journal of Comparative Economics, 12(2), 79-131.

Antalóczy, K., Sass, M. (2015). Through a glass darkly: the content of statistical data on foreign direct investment. Studies in International Economics: Special Issue of Külgazdaság, 1(1), 34-61.

Bryant, C. (2011). Wanhua takes full control of Borsodchem. Retrieved from https://www.ft.com/content/1aadca66-2e2e-11e0-8733-00144feabdc0.

Content, T. (2015). Johnson Controls, Yanfeng form world's largest auto parts supplier. Retrieved from https://eu.ydr.com/story/money/business/2015/10/29/johnsoncontrols-yanfeng-form-worlds-largest-auto-parts-supplier/74802082/.

Damgaard, J., Elkjaer, T. (2017). The Global FDI Network: Searching for Ultimate Investors. Working Paper - Danmarks Nationalbank 2 November 2017 - No. 120.

EIAS (2014). Taiwan's outward foreign direct investment into the European Union and its member states. European Institute for Asian Studies, October 2014.

European Commission (2019). Foreign Direct Investment in the EU. COMMISSION STAFF WORKING DOCUMENT. Brussels, 13.3.2019. SWD (2019) 108 final. Retrieved from https://trade.ec.europa.eu/doclib/docs/2019/march/tradoc_157724.pdf.

Grešš, M. (2019). Slovakia economy briefing: Foreign direct investment in Slovakia. Available at https://china-cee.eu/2019/07/24/slovakia-economy-briefing-foreign-directinvestment-in-slovakia/.

Huang, B., Xia, L. (2018). China | ODI from the Middle Kingdom: What's next after the big turnaround? BBVA Research. Economic Watch. Retrieved from https://www.bbvaresearch.com/wp-content/uploads/2018/02/201802_ChinaWatch_China-Outward-Investment_EDI.pdf.

IMF (2014). Offshore Financial Centers (OFCs): IMF Staff Assessments. Retrieved from https://www.imf.org/external/NP/ofca/OFCA.aspx.

Kaliszuk, E. (2016). Chinese and South Korean investment in Poland: a comparative study. Transnational Corporations Review, 8(1), 60-78. 
Kalotay, K. (2012). Indirect FDI. The Journal of World Investment \& Trade, 13(4), $542-555$.

KSH (2017). Az elsố tízágazat a külföldi leányvállalatoknál foglalkoztatottak száma és aránya szerint (The top ten sectors by number and proportion of employees in foreign subsidiaries). Retrieved from https://www.ksh.hu/docs/hun/xstadat/xstadat_eves/i_qtd013.html. KSH (2018). Munkaügyi és teljesítmény mutatók (Labour and performance indicators). Retrieved from http://statinfo.ksh.hu/Statinfo/haViewer.jsp.

McCaleb, A. (2018). Emerging MNCs in Poland in turbulent times of Belt and Road Initiative and Brexit. Presentation at the Institute for World Economics, Center for Economic and Regional Studies, 8th March 2018. Presentation available at http://www.vki.hu/news/ news_1195.html.

OECD (2015). Measuring International Investment by Multinational Enterprises. Implementation of the OECD's Benchmark Definition of Foreign Direct Investment, 4th edition. OECD, Paris.

Pleschová, G. (2017). Chinese Investment in Slovakia: The Tide May Come In. In: Seaman, J., Huotari, M., Otero-Iglesias, M. (eds.) (2017). Chinese Investment in Europe. A CountryLevel Approach. ETNC Report, French Institute of International Relations (Ifri), Elcano Royal Institute, Mercator Institute for China Studies, 135-140.

Pradhan, J. P. (2017). Indian outward FDI: a review of recent developments. Transnational Corporations, 24(2), 43-70.

Sass, M. (2016). Emerging CEE multinationals in the electronics industry. In: Trąpczyński, Piotr; Puślecki, Łukasz; Jarosinski, Miroslaw (eds.) Competitiveness of CEE economies and business: multidisciplinary perspectives on challenges and opportunities. Cham, Switzerland: Springer International Publishing, pp. 149-173.

Sass, M. (2019). Čínské přimé zahraniční investice ve středovýchodní Evropě (Chinese foreign direct investments in Central Europe). Praha, Masarykova demokratická akademie. Sass, M., Gubik, A., Szunomár, Á. (2019). Ázsiai tőkebefektetések Magyarországon. Miért érkeznek gyakran közvetítô országokon keresztül? (Asian foreign direct investments in Hungary. Why do they come often through intermediary countries?). Statisztikai Szemle, 97(11), 1050-1070.

Seaman, J., Huotari, M., Otero-Iglesias, M. (eds.) (2017). Chinese Investment in Europe. A Country-Level Approach. A Report by the European Think-tank Network on China (ETNC). December 2017. Retrieved from https://www.clingendael.org/sites/default/files/ 2017-12/ETNC_Report_2017.PDF.

Szabo, S. (2019). FDI in the Czech Republic: A Visegrád Comparison. European Commission Economic Brief 042, February 2019. https://ec.europa.eu/info/sites/info/files/economy-finance/eb042_en.pdf.

Varga, Gy. (2018). Az Európán kívüli világból érkező külföldi múködőtőke a Visegrádi országokban. (Outside European foreign direct investments in the Visegrad countries). Földrajzi Közlemények, 142(2), 110-121. 